\title{
INTERNATIONAL TOURIST'S PERCEPTION OF THE DESTINATION IMAGE: A STUDY APPLIED TO LUANDA, ANGOLA
}

\author{
Telma VAN-DUNEM ${ }^{*}$ \\ University of Coimbra, Faculty of Economics, Av. Dias da Silva 165, 3004-512, Coimbra, Portugal, e-mail: telmavanadia89@hotmail.com.
}

\author{
Arnaldo COELHO
}

University of Coimbra /CeBER, Faculty of Economics, Av. Dias da Silva 165, 3004-512, Coimbra, Portugal, e-mail: acoelho@ fe.uc.pt.

\author{
Cristela BAIRRADA
}

University of Coimbra/CeBER, Faculty of Economics, Av. Dias da Silva 165, 3004-512, Coimbra, Portugal, e-mail: cristela.bairrada@uc.pt.

\begin{abstract}
Citation: Van-Dúnem, T., Coelho, A., \& Bairrada, C. (2021). INTERNATIONAL TOURIST'S PERCEPTION OF THE DESTINATION IMAGE: A STUDY APPLIED TO LUANDA, ANGOLA. GeoJournal of Tourism and Geosites, 35(2), 411-418. https://doi.org/10.30892/gtg.35220-667
\end{abstract}

\begin{abstract}
This investigation aims to study the perception of "foreign" tourists regarding the destination image of Luanda, thus evaluating the impact of place identity, optimal distinctiveness and authenticity on positive and negative emotions and how these emotions can influence satisfaction, affective attachment and the intention to revisit. For the analysis of statistical data, the Structural Equation Model was used. Results were based on a sample of 252 tourists. This research showed that place identity influences positive and negative emotions, while optimal distinctiveness and authenticity only impact the positive emotions of the tourist. It was further evidenced that positive and negative emotions have a positive influence on satisfaction, but only positive emotions have an impact on affective attachment and intention to revisit. This investigation shows how positive and negative emotions may link the tourists' perceptions when visiting Luanda to the relationship they want to maintain with the city and to their willingness to return.
\end{abstract}

Key words: tourist perception, positive and negative emotions, Luanda, place identity, optimal distinctiveness, authenticity

\section{INTRODUCTION}

Tourism represents one of the most important industries in the world and plays a key role in the development and competitiveness of many regions. Tourism not only generates economic benefits; it also brings relevant socio-cultural gains (Teixeira and Ferreira, 2019). According to Loi et al., (2017), since 1995, the tourism sector has grown at an average rate of 4.1\% and is expected to account for 1.56 billion international arrivals per year over the next 25 years (Loi et al., 2017). By consuming tourism and leisure services, tourists not only expect professional services, but also want to satisfy emotional experiences, so understanding tourists' emotions is crucial for service companies (Brunner-Sperdin et al., 2012). Therefore, it is not enough to guarantee and offer quality services that meet the standards, it is also important to consider the willingness of the tourist to acquire experiences and feel emotions that contribute to maximizing satisfaction (Tlili and Amara, 2016).

Prior literature, however, lacks consistent and appropriate instruments to help destination managers identify distinctive local characteristics (Truong et al., 2018). Furthermore, understanding and measuring tourists' emotional experiences with the destination and how these emotions influence affection to the place are little explored (Hosany, 2012). At the same time, the coexistence of positive and negative emotions and their impact on customer behaviour lacks further investigation, namely on customer satisfaction (Xu et al., 2019). There are few studies that have looked at tourists' behaviours towards visiting Africa, as this continent is an emerging destination choice that has not previously attracted applied research (Mlozi and Pesämaa, 2013).

The main objective of this study is to fill this gap, presenting a model that can help to understand how the place identity, optimal distinctiveness and authenticity can contribute to the tourists' emotions, and in turn, how the emotional feeling can affect satisfaction, affective attachment to the place and intention to revisit. To meet these objectives, cross sectional data was collected based on a structured questionnaire with 252 respondents. Structural equation modelling was used to test the hypotheses developed in this research to achieve the proposed objectives. This study presents itself as innovative, since it proposes a new relationship between the variables place identity, optimal distinctiveness and authenticity with positive and negative emotions and their role, linking these variables with the bonds tourists may establish with the place. Additionally, this investigation takes place in Luanda, Angola's capital. Luanda is the capital of Angola and is in the northwestern zone of the country and has 9 municipalities. Luanda is the third largest Portuguese-speaking city, after the Brazilian cities of São Paulo and Rio de Janeiro, and in 2014 the province had 6,945,386 inhabitants, according to the National Statistics Institute (Instituto Nacional de Estatística, 2018). In Angola, the tourism sector is relatively new, worth 3.5\% of GDP (Ministério da Hotelaria e Turismo, 2018). The main reason for foreign tourist travel to Angola was "service" tourism, with a total weight of 59\% in the biennium 2016 - 2017. Business, with 28\%, and holidays, with 13\%, were in second and third place, respectively (Ministério

\footnotetext{
* Corresponding author
} 
da Hotelaria e Turismo, 2018). According to the Ministry of Hospitality and Tourism (2018), Europeans are the on es who travel to Angola most, and Portugal is the largest emitter of tourists, in a movement that needs to be increased.

\section{MATERIALS AND METHODS}

\section{Tourist Emotion}

According to Yang et al. (2011), emotion is defined as a psychological state that arises from cognitive evaluations of events or thoughts. The authors reinforce that emotion has a phenomenological tone, which is accompanied by physiological processes and is often physically expressed (gestures, posture, facial features). Emotion is also considered as an affective state characterized by an intense feeling associated with something specific (such as a person, object, or event) that stimulates a specific response (Hosany et al., 2017). These authors suggest that the psychology literature refers to two main theoretical approaches to the study of emotions, namely categorical (emotion specificity) and dimensional (valence-based). For them, categorical approaches conceptualize emotions as a set of idiosyncratic affective states (e.g., joy, disappointment, surprise) while dimensional approaches conceptualize emotions using few dimensions, such as positive and negative or pleasure and arousal. Each emotional experience is influenced by the environment and represents the consumer's real perceptions and feelings about a service product (Deng et al., 2013). On the other hand, it is important to note that these authors highlight the existence of two types of consumer emotions, which are: positive emotions and negative emotions (Deng et al., 2013; Pestana et al., 2020). These authors also point out that the customer behaviour shows that both positive and negative emotions have significant positive or negative influence on consumer satisfaction. According to Del Bosque and San Martín (2008), emotions are necessary to understand consumer psychology and are expressed in terms of feelings about the service. Emotions can, moreover, be important in tourism because the experimental component and ambiguity of the experience are extraordinary: the bigger the gap between the tourist's expectations and the experience provided, the bigger will be the likelihood of the emotions generated (Xu et al., 2019). Regarding the formation of emotions, evaluation theories establish that the emotions of individuals are influenced by their evaluations and interpretations of a specific event (Del Bosque et al., 2008). In tourism, emotions are ubiquitous and play a central role in defining memorable experiences. Tourist emotional reactions are fundamental precursors of post-consumer behaviour (Hosany et al., 2015). According to appraisal theory Lazarus (1991), environment, context or situation leads the tourist through an evaluation process that triggers emotions and an emotional response that turns into positive (when emotions are positive) - desire to stay, to return, to explore, to enjoy - or negative (when emotions are negative) - to leave, not return, not explore, not enjoy - behaviours (Yang et al., 2011). Most of the past investigation tends to ignore the likelihood of the coexistence of positive and negative emotions and the fact that conflicting emotions may arise, especially in exceptional situations (Xu et al., 2019). In fact, they seem to be more frequent than expected, and tourism and the diverse experiences it may provide may be a very interesting field to investigate the formation and influence of positive and negative emotions.

\section{ANTECEDENTS OF TOURIST EMOTION \\ Place Identity}

A place is a setting to which are attributed meanings based on human experiences, relationships, emotions, and thoughts. The place consists of the physical environment, activities performed in that environment, and social or psychological processes (Wang and Chen, 2015). Identity is seen as a set of meanings attached to self that serves as a standard or reference that guides behaviour in situations (Wang and Chen, 2015). Thus, a place identity is determined not only by the physical components, but also by the meaning and association developed between people and place. Within that concept of place identity, Yuksel et al. (2010) clarifies that this variable defines the connection between the self and a particular place that consists of a collection of "memories, interpretations, ideas and related feelings about physical settings as well as types of settings" (Yuksel et al., 2010: 276). The term "place identity" is thus used to capture a wide range of social relationships that contribute to the construction of a "sense of place", a sense that allows people to feel that they "belong" to a place, or that a place "belongs" to them (Kneafsey, 1998). Identities are culturally constructed, i.e., organized around a specific set of values whose meaning and shared use are marked by specific codes of self-identification: the community of believers, the icons of nationalism, the geography of the place (Lima et al., 2007). According to Kneafsey (1998) the place identity of the destination is created to meet the needs of tourists, because when tourists visit a place, they develop emotional ties with the place. According to Dias et al. (2017) people's emotional relationships with places contain a wide range of physical contexts and emotions. Knez et al. (2018) suggest that place identity may influence variables like well-being, through the effect of emotions.

Consequently, the following hypothesis is proposed:

Hypothesis1a: There is a relationship between place identity and positive emotions.

Hypothesis1b: There is a relationship between place identity and negative emotions.

\section{Optimal Distinctiveness}

In response to a heightened need for inclusion or differentiation, individuals engage processes such as emotional and trait self-stereotyping, altering judgments of group memberships, perceptions of consensus, and social comparison (Goldman et al., 2016). The optimal distinction can be defined as the level of freedom to remain different while still being part of the group's identity (Zenker et al., 2017). People are selective in finding similarities (e.g., age, gender, or social status) while still recognizing other differences to satisfy their need to remain recognizable as individuals (Zenker et al., 2017).

In the tourism sector, this variable represents the fact that a destination can be perceived as being unique, in other words, a destination that has distinct characteristics from other competing offers. This distinctiveness is crucial and the marketing strategy should reinforce it in the development of products and services related to the place, providing a unique and innovative experience, 
based on the local particularities (Truong et al., 2018). Therefore, the same authors point out that tourists recognize when destination specificity has been integrated into tourist products, and this affects satisfaction with the place they have visited, namely through its emotional value. The authors point out that tourists are satisfied when the destination provides them with unique moments that differ from other destinations, generating memorable emotions.

Consequently, the following hypothesis is proposed:

Hypothesis2a: There is a relationship between optimal distinctiveness and positive emotions.

Hypothesis $2 \mathrm{~b}$ : There is a relationship between optimal distinctiveness and negative emotions.

\section{Authenticity}

Cunha (2011) argues that the first motivation for travel is linked to the search for authenticity and that tourist knowledge is motivated by the desire for an authentic experience. According to Cunha (2011), the complex nature of authenticity in tourism can be classified into objective authenticity, constructive authenticity and existential authenticity, the first two being related to objects and the last to activities. Objective authenticity refers to the authenticity of objects (e.g., museums and monuments) and, in this case, authentic experiences are felt by the recognition that the objects visited are authentic (Ram et al., 2016; Cunha, 2011; Kim and Kim, 2020). In this sense, what the tourist seeks is a symbolic authenticity. Constructivists see authenticity as a dynamic concept in the sense that it can be attributed to a visited place that was initially perceived as inauthentic, and suggest that "tourist experiences can be authentic even when tourists are fully aware that reality it is staged (symbolic authenticity)" (Cunha, 2011: 16). Authenticity is recognized as a universal value and one of the driving forces that motivate tourists to travel, the search for authenticity being considered one of the keys to tourism trends (Cunha, 2011).

Authenticity as a "state of being" includes a philosophical discussion of the self in context (external world) and a reflection of how important it is to balance two parts of itself: rational and emotional. This perspective defines existential authenticity as an alternative tourism experience, focusing on how open the tourists are to their experiences in the threshold spaces that tourism offers (Ram et al., 2016). In tourist experiences people feel that they are much more authentic and freer than in their daily lives, not because they discover objects, but because they are engaged in activities free from daily constraints (Cunha, 2011). The context that influences experiences, the heritage value of destinations and the iconicity of tourist attractions can all affect the authenticity of visitor attractions. This is particularly pertinent to heritage tourism destinations, where visitors travel to experience the places, artefacts, and activities that authentically represent history and people from the past and present (Ram et al., 2016). The sense of authenticity as a traveller may be linked to the emotion produced by being the only foreigner among the natives, or on a beach, or on public transportation (Piscitelli, 2007). However, the most intense point of these sensations is reached through experiences and emotions (Piscitelli, 2007). In fact, Jang and Ha (2015) showed how authenticity could influence emotions, both positively and negatively. Consequently, the following hypothesis is proposed:

Hypothesis3a: There is a relationship between authenticity and positive emotions.

Hypothesis 3 b: There is a relationship between authenticity and negative emotions.

\section{CONSEQUENCES OF TOURIST EMOTION}

\section{Satisfaction with destination}

Each destination seeks to attract as many tourists as possible through its main tourism products, such as accommodations, entertainment packages, city infrastructure and transportation and experiences provided (Loi et al., 2017). Satisfaction depends on the experience of using services and has been treated as a one-dimensional construct that might vary over a range from dissatisfaction to satisfaction. According to the World Tourism Organization, satisfaction is a psychological state that involves a sense of well-being and pleasure resulting from obtaining a product or service. Tourist satisfaction is also considered as the result of comparing "a tourist's experience at the destination visited and the expectations about the destination" (Sukiman et al., 2013: 80). It is a key element in the success of a destination, as satisfaction leads to tourist loyalty (Chi et al., 2018). For this, it is important to understand what facilitates a satisfying experience. If visitors have a satisfying experience, they are more likely to return, and are also more likely to recommend a destination to others (Plunkett and Brooks, 2018). In this way we can see the fact that customer satisfaction has always been considered an essential objective in all markets, and this is also true for tourism (Garín-Muñoz and Moral, 2017). For Sukiman et al., (2013) a tourism product is any offer that can satisfy the need to travel and escape routine. It may consist of one or a combination of components, including physical goods, services, experiences, events, people, places, properties, organizations, information, and ideas that generate emotions, when used. Therefore, in tourist destination management, maximizing emotions and travel satisfaction is crucial to a successful business. Therefore, tourist satisfaction is one of the primary variables for sustaining competitive business in the tourism industry, as it affects destination choice and the consumption of products and services (Rajesh, 2013). Tlili et al., (2016) show that positive emotions during the service experience increase satisfaction, while negative emotions decrease satisfaction. In the same vein, Io (2018) shows that emotions may predict tourists' satisfaction. Therefore, the following hypothesis is proposed:

Hypothesis4a: There is a relationship between positive emotions and satisfaction.

Hypothesis4b: There is a relationship between negative emotions and satisfaction.

\section{Affective Attachment}

Social theorists believe that places are sources of identification and affiliation that provide meaning and purpose for life. Places are significant through their associated attitudes, values, and beliefs. Affective attachment to a place continues to be defined as the emotional bond between an individual and a particular spatial environment (Prayag and Ryan, 2012). Scannell 
and Gifford (2010) emphasize place attachment as a multifaceted concept that characterizes the bonding between individuals and their important places. Other authors define place attachment as a positive affective bond between an individual and a specific place, the main characteristic of which is the tendency of the individual to maintain proximity to that same place (Hidalgo and Hernández, 2001). Scannell and Gifford (2010) argue that affective attachment is a multidimensional concept involving psychological processes and place dimensions. According to these authors, the first dimension is centred on the individual. It consists of reflecting on the following questions: who is attached? To what extent is the attachment based on individually and collectively held meanings? The second dimension is the psychological process. It allows us to reflect on the following questions: how are affect, cognition, and behaviour manifested in the attachment? Finally, the third dimension is the object of the attachment and questions like what the attachment is and what the nature of that place is (Scannell and Gifford, 2010).

When tourists visit a place, they develop emotional bonds with it, and this is important for understanding their behaviour (Gu and Ryan, 2008). An experience in a tourist destination, in a place or accommodation, leads to memories, as tourism is concerned with "helping people build stories and collect memories" (Loureiro, 2014: 3). Thus, the place attachment is considered as an indicator of how tourists consider the place in their tourism experiences (Gross and Brown, 2006). Affective attachment is thus defined as being an emotional link to a particular environment (Yuksel et al., 2010). These affective experiences potentially modify consumer behaviour, creating or strengthening attachment to the place, and so consumers' affective experiences, while visiting a place, directly influence their behaviour (Orth et al., 2012).

According to Grisaffe and Nguyen (2011) there is a relationship between emotions and attachment and Hosany et al. (2017) show that positive emotions about a place reinforce a sense of attachment through person-place interactions. Emotions related to the destination experience contribute to the formation of place attachment. The authors also point out that tourism experiences are not devoid of negative emotions (Hosany et al., 2017; Ouyang et al., 2017). Thus, we assume that:

Hypothesis5a: There is a relationship between positive emotions and affective attachment.

Hypothesis5b: There is a relationship between negative emotions and affective attachment.

\section{Revisit Intention}

From the point of view of the consumption process, tourist behaviour is divided into three stages: pre-visit, during the visit and post-visit (Mat Som et al., 2012). The revisit intention consists of positive behavioural results from satisfactory tourist experiences. Satisfied tourists are more likely to revisit the destination (Huang and Hsu, 2009; Mat Som et al., 2012; Seetanah et al., 2020). Satisfied visitors have positive attitudes toward their destination. Satisfaction with the experience at a destination positively affects the intention to revisit (Huang and Hsu, 2009). In the tourism industry, there is empirical evidence that tourist satisfaction is a strong indicator of the intention to revisit and recommend the destination to others (Machado and Gosling, 2010). According to the same authors, reasons for why people return to their destination have been identified: 1) If the tourist is satisfied with his destination, he may return to the place in order to reduce the risk of going to another place he does not like; 2) In a destination already known, the tourist is already more familiar with the type of people he will meet at the place; 3) The tourist tends to show the destination to other people; 4) He explores and knows the destination more deeply and 5) There is an emotional and affective attachment with the destination. Su et al. (2014) consider that if a tourist destination can extract positive emotions and eliminate negative emotions at the same time, then it can be hypothesized that tourists are more likely to revisit the destination. In the same vein, Io (2018) shows how emotions might influence the intention to return.According to Mat Som et al. (2012) destination attributes affect perceived quality, which affects satisfaction, which in turn leads to the intention to revisit. The author also found that satisfaction influences the tourist's intention to revisit in the short term, while novelty-seeking influences the tourist's intention to revisit in the midterm, and long term. Similarly, Huang and Hsu (2009) demonstrated that the intention to revisit is determined by sets of interrelated stimuli (sources of information), psychological factors (sociopsychological motivation for travel) and images (perceptive or cognitive and affective images). Past travel experiences could also significantly influence the behaviour of tourists to revisit a destination (Huang and Hsu, 2009; Hosany et al., 2015). So, we assume that:

Hypothesis6a: H6.a: There is a relationship between positive emotions and revisit intention.

Hypothesis6b: H6.b: There is a relationship between negative emotions and revisit intention.

Hypothesis7: There is a relationship between satisfaction and revisit intention.

Hypothesis8: There is a relationship between affective attachment and revisit intention.

According to figure 1, the conceptual model presents the set of hypotheses that express the objectives of this investigation.

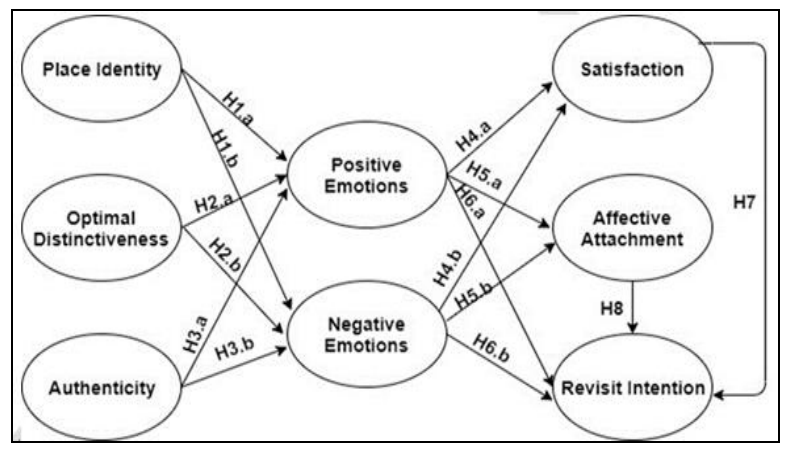

Figure 1. Conceptual model (Source: Self elaboration)

The sample population for this study consisted of tourists from various parts of the world who visited Luanda in the last 12 months. A total of 252 tourists agreed to participate in this survey. Data was collected between January and March 2019. The self-administered questionnaires were distributed at Luanda International Airport, at several different hotels and other touristic places in the city. Regarding the data collected, we found that the majority of tourists $(59.1 \%)$ were male, $40.9 \%$ were female. With regard to age, 105 $(41.7 \%)$ are between 36 and 45 years and the average is 40 years old. Regarding the academic level, it was observed that more than half of the respondents, $145(57.5 \%)$ have a degree. $57(22,6 \%)$ have a Master's/PhD and 45 individuals (17.9\%) have a secondary education. $82.9 \%$ have been in the city more than once. 
The measures to assess each variable were collected and adapted from prior investigations. Place Identity was measured using the scale from Yuksel et al. (2010). Optimal Distinctiveness was measured using the scale from Zenker et al., (2017) and Authenticity was measured using the scale from Ram et al., (2016). Positive emotions and Negative emotions were measured according to the scale proposed by Hosany et al. (2016). Satisfaction was measured using the scale from Songshan et al. (2009) and Affective attachment was measured using the scale from Yuksel et al. (2010). Finally, Revisit Intention was measured using the scale from Songshan et al. (2009). To measure all the variables, the questionnaire was based on a 7-point Likert scale. The items used to measure each variable were translated from English to Portuguese and then from Portuguese to English to ensure the items remain true to the original. Subsequently, a pre-test was performed to ensure the comprehensibility of the questionnaire. Confirmatory factor analysis (CFA) was performed to assess the psychometric properties of the scales and the measurement model fit, using AMOS 25 and we concluded that the model shows a good fit (Incremental Fit Index = 0.958; Tucker Lewis Fit Index =0.951; Comparative Fit Index =0.958; Root Mean Square Error of Approximation =0.071; Chi Square $(\chi 2)=2.245)$. After analysing Composite Reliability and Average Variance Extracted, it was found that all constructs used in the conceptual model presented values higher than 0.7 and 0.5 , respectively (Hair et al., 2014). The discriminant validity of latent variables is evident if the squared correlation between them is lower than the average variances extracted (Fornell and Larcker, 1981). Therefore, considering that the squared correlations between the variables are, in this study, lower than the average variances extracted for all variables, it is concluded that there is discriminant validity (Table 1).

Table 1- Squared correlations. Cronbach alpha. Composite reliability. Average variances extracted

\begin{tabular}{|l|r|r|r|r|r|r|r|r|r|r|r|}
\hline Variables & \multicolumn{1}{|c|}{ SD } & \multicolumn{1}{c|}{ X1 } & \multicolumn{1}{c|}{ X2 } & \multicolumn{1}{c|}{ X3 } & \multicolumn{1}{c|}{ X4 } & \multicolumn{1}{c|}{ X5 } & X6 & X7 & X8 & AVE & CR \\
\hline Place Identity (X1) & 1.98 & 0.95 & & & & & & & & 0.87 & 0.98 \\
\hline Optimal Distinctiveness (X2) & 1.63 & 0.53 & 0.93 & & & & & & & 0.83 & 0.93 \\
\hline Authenticity (X3) & 1.39 & 0.64 & 0.57 & 0.92 & & & & & & 0.79 & 0.92 \\
\hline Positive emotions (X4) & 1.72 & 0.82 & 0.59 & 0.70 & 0.97 & & & & & 0.82 & 0.97 \\
\hline Negative emotions (X5) & 1.63 & -0.33 & -0.19 & -0.25 & -0.36 & 0.95 & & & & 0.86 & 0.95 \\
\hline Satisfaction (X6) & 1.72 & 0.65 & 0.51 & 0.59 & 0.79 & -0.47 & 0.95 & & & 0.88 & 0.96 \\
\hline Affective attachment (X7) & 2.15 & 0.78 & 0.45 & 0.58 & 0.82 & -0.31 & 0.69 & 0.97 & & 0.92 & 0.97 \\
\hline Revisit Intention (X8) & 2.11 & 0.56 & 0.43 & 0.48 & 0.65 & -0.25 & 0.60 & 0.65 & 0.98 & 0.92 & 0.98 \\
\hline
\end{tabular}

Notes: Diagonal entries are Cronbach's alpha coefficients. SD- standard deviation. $\mathrm{CR}=$ Composite reliability. AVE $=$ Average variance extracted

\section{FINDINGS AND DISCUSSION}

After establishing the hypotheses proposed in the investigation, the Structural Equation Model was estimated through AMOS (version 25). The model presents a good fit (Incremental Fit Index 0.955; Tucker Lewis Fit Index = 0.949; Comparative Fit Index =0.955; Root Mean Square Error of Approximation $=0.072$; Chi Square $(\chi 2)=2.300($ Table 2).

Table 2- Results

\begin{tabular}{|c|c|c|c|c|c|}
\hline & & & Hyp & SRW & P \\
\hline Place Identity & $\rightarrow$ & Positive emotions & H1a & 0.601 & $* * *$ \\
\hline Place Identity & $\rightarrow$ & Negative emotions & H1b & -0.29 & $* * *$ \\
\hline Optimal Distinctiveness & $\rightarrow$ & Positive emotions & H2a & 0.128 & $* * *$ \\
\hline Optimal Distinctiveness & $\rightarrow$ & Negative emotions & H2b & 0.009 & n.s. \\
\hline Authenticity & $\rightarrow$ & Positive emotions & H3a & 0.247 & $* * *$ \\
\hline Authenticity & $\rightarrow$ & Negative emotions & H3b & -0.078 & n.s. \\
\hline Positive emotions & $\rightarrow$ & Satisfaction & H4a & 0.719 & $* * *$ \\
\hline Negative emotions & $\rightarrow$ & Satisfaction & H4b & -0.222 & $* * *$ \\
\hline Positive emotions & $\rightarrow$ & Affective attachment & H5a & 0.819 & $* * *$ \\
\hline Negative emotions & $\rightarrow$ & Affective attachment & H5b & -0.02 & n.s. \\
\hline Positive emotions & $\rightarrow$ & Revisit Intention & H6a & 0.252 & $* * *$ \\
\hline Negative emotions & $\rightarrow$ & Revisit Intention & H6b & 0.024 & n.s. \\
\hline Satisfaction & $\rightarrow$ & Revisit Intention & H7 & 0.195 & $* * *$ \\
\hline Affective attachment & $\rightarrow$ & Revisit Intention & H8 & 0.313 & $* * *$ \\
\hline
\end{tabular}

Notes: $* * * \mathrm{p}<0.01 ; \mathrm{n} . \mathrm{s}$ : hypothesis not supported

Place identity has a significant impact on positive and negative emotions ( $S R W=0.601, \mathrm{p}<0.01),(\mathrm{SRW}=-0.29$, $\mathrm{p}<0.01)$, thus supporting H1.a and H1.b. It is recalled that place identity has been defined as a more emotional, or even symbolic, dimension of place attachment, which is formed and strengthened over time (Wang and Chen, 2015). According to Knez et al. (2018) emotions are the linking element that transfer the effects from place features, like identity, to attitudes and behaviours, like memorability, affect, revisiting, among others. These results suggest that the identity of the place must be an important factor in the perceptions of the characteristics of the destination in order to provide positive emotions and avoid negative emotions, to tourists. Regarding the relationship between optimal distinctiveness and positive emotions, the result is statistically significant (SRW $=0.128, \mathrm{p}<0.01$ ), thus supporting H2.a. However, the influence of the optimal distinctiveness on negative emotions ( $\mathrm{SRW}=0.009, \mathrm{p}>0.1$ ) was not significant, not supporting H2.b. In fact, positive emotions appear to be determinant, more frequent and more decisive. When on vacation or in touristic activities, positive emotions may arise more easily and, somehow, there might be some openness to inconvenience or to "bad moments", waiting for the best moments and 
the biggest emotions provided by the experience. Perhaps, the tourist's good mood tends to mitigate the negative impacts and the negative emotions (Lee et al., 2008). In fact, the same authors found stronger effects with positive than with negative emotions. The relationship between authenticity and positive emotions is statistically significant $(\mathrm{SRW}=0.247, \mathrm{p}<0.01)$, which supports H3.a. The result of the relationship between authenticity and negative emotions is negative, as expected, but statistically insignificant (SRW = -0.078, p> 0.1), therefore, not supporting H3.b. Even if these relationships have so far been little explored, the results are similar to the previous hypotheses, showing how positive emotions might prevail in a touristic experience.

Positive emotions (SRW $=0.719, \mathrm{p}<0.01)$ and negative emotions (SRW $=-0.222, \mathrm{p}<0.01)$ are related to satisfaction with destination, therefore supporting H4.a and H4.b. According to the study developed by Oliver (1993), emotions (positive and negative) influence the satisfaction with destination. The more frequent positive emotions are during the tourist experience, the higher the level of satisfaction (Io, 2018). And the less frequent negative emotions are during the tourist experience, the higher the level of satisfaction. Emotions occur as a result of cognitive and emotional assessments of the experience, that is, the satisfaction of the tourists is based on their own experiences. These relationships support the importance of the touristic managers' betting on the quality of the services and experiences they offer to tourists, in order to provide them with memorable emotions and avoiding the negative ones. The results also show a positive relationship between positive emotions and affective attachment (SRW $=0.819, \mathrm{p}<0.01$ ), supporting H5.a. Unlike what was predicted in our conceptual model, the data were unable to support the relationship between negative emotions and affective attachment $(\mathrm{SRW}=-0.02, \mathrm{p}>0.1)$, H5.b. At the same time, positive emotions contribute positively to the revisit intention ( $S R W=0.252, \mathrm{p}<0.01$ ), but the negative ones have no significant influence on revisit intention ( $\mathrm{SRW}=0.024, \mathrm{p}>0.1$ ), thus supporting H6.a, but not H6.b. Positive emotions were found to increase affective attachment and the likelihood of revisiting intentions, while negative emotions show the opposite but not significant influence. Apparently, as already suggested, positive emotions might be dominant or at least, more present and more influential on touristic experiences. In fact, the same statistical insignificant relationship between negative emotions and these desired outcomes have also been found by Lee et al. (2008) and Faullant et al. (2011).

There is a positive relationship between destination satisfaction and revisit intention ( $\mathrm{SRW}=0.195$, p <0.01), supporting H7. This link had also been found by Huang and Hsu (2009); Mat Som et al. (2012) and Hosany et al. (2015), among others. Satisfaction is sometimes a prerequisite to loyalty and the intention to revisit: a destination that provides a pleasant and satisfactory visit and experience is more likely to attract the interest of its visitors to come back and try and discover new features and new experiences as well as to disseminate a positive word of mouth about the destination (Chi et al., 2018).

Additionally, this research shows that affective attachment to a place also has a positive impact on revisit intention $(\mathrm{SRW}=$ 0.313, p <0.01), therefore supporting H8. Many authors have previously established the relationship between affective attachment to a place and revisit intention (e.g., Yuksel et al., 2010; Loureiro, 2014). However, with this study it is once again argued that the greater the emotional connection between the tourist and the place, the greater the intention to revisit it, namely through affective attachment. In recent years, several studies have recognized the importance of emotions in tourism (Hosany, 2012). One of the reasons that has led to this growing demand has to do essentially with the fact that some models, essentially based on more rational variables, have failed to explain the relationship tourists feel with their destinations. This investigation was developed to investigate the antecedents and consequences of positive and negative emotions in order to understand the perception that international tourists have about Luanda. Results show that, somehow, tourists are looking for experiences that might provide strong and positive emotions that might mitigate the power and effects of negative emotions. This is one of the main highlights of this investigation, identifying how positive and negative emotions may act differently in the tourists' attitudes and behaviours. These results can be useful for tourism operators, managers and decision makers, as they identify the factors that provide positive emotions for tourists making it easier to create strategies that aim to meet the expectations of tourists and consequently increase the affective attachment to destination and revisit intention.

\section{Theoretical and Practical Contributions}

This investigation intended to identify how positive and negative emotions might link the tourists' perceptions about destination, to the relationship they want to maintain with it and to the willingness to return. Therefore, the results present 3 major contributions: (1) identifying the different action and effects of positive and negative emotions, which might act differently in touristic activities or experiences; (2) introducing the place attachment on the relationship between emotions and intention to revisit as well as an outcome of these emotions, especially when positive; (3) and identifying the chain of effects between the destination features and the way the tourists want to relate with the place and their intentions to revisit, through the effects of emotions and satisfaction. The results show how positive and negative emotions act differently giving new clues to investigation and practice. These results might also give important clues to managers and professionals acting in the touristic sector. The positive impact of satisfaction and affective attachment on the revisit intention, identified in this work, reinforces Loureiro's theory (2014), which argues that affective attachment implies identification with its physical attributes, but also the links developed in relationships with other people, claiming that social relationships are more important than physical attributes, providing stronger and more memorable experiences and emotions.

Therefore, a tourist with strong connections to a destination tends to revisit it and look to visit and experience new and different features, but it is important that tour managers rely on services that can ensure positive experiences and positive emotions in order to develop deep positive memories that will gradually reinforce the revisit intention. Accordingly, negative emotions are to be avoided, but these results are very interesting for tourist operators in Angola: not always infrastructure, staff, services and touristic offer are prepared to offer conventional services in the terms provided by other countries, especially in other continents. However, if the impressions, the experiences and the positive emotions provided are really strong and memorable, they might obliterate the possible negative effects of any negative emotion that might arise 
due to the country's specificities. We believe that knowing tourists' perceptions of Luanda as well as how their revisit intentions are created will enable managers to better plan and develop their strategies to meet tourists' expectations.

\section{LIMITATIONS AND FUTURE RESEARCH LINES}

This investigation is based on cross sectional data collected from a convenience sample with the obvious limitations in terms of generalizability and in terms of establishing a true causality between the concepts adopted. A longitudinal investigation might provide a better comprehension of the proposed relationships. Additionally, the measurement of emotions might introduce several difficulties and the lapse of time between the experience and the measurement might introduce significant bias. We therefore suggest the adoption of a qualitative investigation using, namely, ethnography, to capture emotions at the moment they are produced, identifying their nature and intensity. It might also be interesting to explore tourist perceptions of risk (insecurity / instability) provided by destination, especially in countries with a high level of poverty.

\section{REFERENCES}

Brunner-Sperdin, A., Peters, M., \& Strobl, A. (2012). It is all about the emotional state: Managing tourists' experiences. International Journal of Hospitality Management, 31(1), 23-30. https://doi.org/10.1016/j.ijhm.2011.03.004

Chi, C.G.Q., Pan, L., \& Del Chiappa, G. (2018). Examining destination personality: Its antecedents and outcomes. Journal of Destination Marketing and Management, 9(January), 149-159. https://doi.org/10.1016/j.jdmm.2018.01.001

Cunha, L. (2011). Autenticidade e Inovação: factores de renovação dos destinos turísticos maduros [Authenticity and Innovation: factors for the renewal of mature tourist destinations]. Cogitur. Journal of Tourism Studies, 4, 9-28 (in Portuguese).

Del Bosque, I.R., \& San Martín, H. (2008). Tourist satisfaction a cognitive-affective model. Annals of Tourism Research, 35(2), 551-573. https://doi.org/10.1016/j.annals.2008.02.006

Deng, W.J., Yeh, M.L., \& Sung, M.L. (2013). A customer satisfaction index model for international tourist hotels: Integrating consumption emotions into the American customer satisfaction index. International Journal of Hospitality Management, 35, 133-140. https://doi.org/10.1016/j.ijhm.2013.05.010

Dias, J.A., Correia, A., \& Cascais, T. (2017). Traits in Tourists' Experiences: Senses, Emotions and Memories. In: Correia A., Kozak M., Gnoth J., Fyall A. (eds) Co-Creation and Well-Being in Tourism, Tourism on the Verge, Springer, Cham. https://doi.org/10.1007/978-3-319-44108-5_14

Faullant, R., Matzler, K., \& Mooradian, T.A. (2011). Personality, basic emotions, and satisfaction: Primary emotions in the mountaineering experience. Tourism Management, 32(6), 1423-1430. https://doi.org/10.1016/j.tourman.2011.01.004

Fornell, Claes \& Larcker, D.F. (1981). Evaluating Structural Equation Models with Unobservable Variables and Measurement Error. Journal of Marketing Research, 4(18), 39-50. https://doi.org/10.1177/002224378101800104

Garín-Muñoz, T., \& Moral, M. (2017). Determinants of Satisfaction with an Urban Tourism Destination: The Case of Barcelona. Journal of Reviews on Global Economics, 6(December 2013), 113-128.

Goldman, M.M., Chadwick, S., Funk, D.C., \& Wocke, A. (2016). I am distinctive when I belong: Meeting the need for optimal distinctiveness through team identification. International Journal of Sport Management and Marketing, 16(3), 198-220. https://doi.org/10.1504/IJSMM.2016.077930

Grisaffe, D.B., \& Nguyen, H.P. (2011). Antecedents of emotional attachment to brands. Journal of Business Research, 64(10), 1052-1059. https://doi.org/10.1016/j.jbusres.2010.11.002

Gross, M.J., \& Brown, G. (2006). Tourism experiences in a lifestyle destination setting: The roles of involvement and place attachment. Journal of Business Research, 59(6), 696-700. https://doi.org/10.1016/j.jbusres.2005.12.002

$\mathrm{Gu}, \mathrm{H} .$, \& Ryan, C. (2008). Place attachment, identity and community impacts of tourism-the case of a Beijing hutong. Tourism Management, 29(4), 637-647. https://doi.org/10.1016/j.tourman.2007.06.006

Hair, J.F., Black, W.C., Babin, B.J., \& Anderson, R.E. (2014). Multivariate Data Analysis. Exploratory Data Analysis in Business and Economics, Pearson Ed.

Hidalgo, M.C., \& Hernández, B. (2001). Place attachment: Conceptual and empirical questions. Journal of Environmental Psychology, 21(3), 273-281. https://doi.org/10.1006/jevp.2001.0221

Hosany, S. (2012). Appraisal determinants of tourist emotional responses. Journal of Travel Research, 51(3), 303-314. https://doi.org/10.1177/0047287511410320

Hosany, S., Prayag, G., Deesilatham, S., Cauševic, S., \& Odeh, K. (2015). Measuring Tourists' Emotional Experiences: Further Validation of the Destination Emotion Scale. Journal of Travel Research, 54(4), 482-495. https://doi.org/10.1177/0047287514522878

Hosany, S., Prayag, G., Van Der Veen, R., Huang, S., \& Deesilatham, S. (2017). Mediating Effects of Place Attachment and Satisfaction on the Relationship between Tourists' Emotions and Intention to Recommend. Journal of Travel Research, 56(8), 1079-1093. https://doi.org/10.1177/0047287516678088

Huang, S., \& Hsu, C.H.C. (2009). Effects of travel motivation, past experience, perceived constraint, and attitude on revisit intention. Journal of Travel Research, 48(1), 29-44. https://doi.org/10.1177/0047287508328793

Io, M.U. (2018). The relationships between positive emotions, place attachment, and place satisfaction in casino hotels. International Journal of Hospitality \& Tourism Administration, 19(2), 167-186. https://doi.org/10.1080/15256480.2017.1305315

Jang, S., \& Ha, J. (2015). The influence of cultural experience: Emotions in relation to authenticity at ethnic restaurants. Journal of Foodservice Business Research, 18(3), 287-306. https://doi.org/10.1080/15378020.2015.1051436

Kim, M., \& Kim, J. (2020). Destination authenticity as a trigger of tourists' online engagement on social media. Journal of Travel Research, 59(7), 1238-1252. https://doi.org/10.1177/0047287519878510

Kneafsey, M. (1998). Tourism and place identity: A case-study in rural Ireland. Irish Geography, 31(2), 111-123. https://doi.org/10.1080/00750779809478623

Knez, I., Butler, A., Sang, Å.O., Ångman, E., Sarlöv-Herlin, I., \& Åkerskog, A. (2018). Before and after a natural disaster: Disruption in emotion component of place-identity and wellbeing. Journal of Environmental Psychology, 55, 11-17. https://doi.org/10.1016/j.jenvp.2017.11.002.

Lazarus, R.S. (1991). Emotion and adaptation. New York: Oxford UniversityPress.

Lee, Y.K., Lee, C.K., Lee, S.K., \& Babin, B.J. (2008). Festivalscapes and patrons' emotions, satisfaction, and loyalty. Journal of business research, 61(1), 56-64. https://doi.org/10.1016/j.jbusres.2006.05.009

Lima, V.R., Marinho, M., \& Brand, A. (2007). História, Identidade e Desenvolvimento Local: Questões e Conceitos. [History, Identity and Local Development: Issues and Concepts.] Revista História \& Perspectivas, 1, 363-388 (in Portuguese). 
Loi, L.T.I., So, A.S.I., Lo, I.S., \& Fong, L.H.N. (2017). Does the quality of tourist shuttles influence revisit intention through destination image and satisfaction? The case of Macao. Journal of Hospitality and Tourism Management, 32, 115-123. https://doi.org/10.1016/j.jhtm.2017.06.002

Loureiro, S.M.C. (2014). The role of the rural tourism experience economy in place attachment and behavioral intentions. International Journal of Hospitality Management, 40, 1-9. https://doi.org/10.1016/j.ijhm.2014.02.010

Machado, D.F.C., \& Gosling, M. (2010). A imagem do destino turístico Ouro Preto e seus reflexos na lealdade, na satisfação e na divulgação boca a boca [The image of Ouro Preto tourist destination and its reflexes on loyalty, satisfaction and word of mouth]. Observatório de Inovação Do Turismo, 5(3), 1-28 (in portuguese). http://dx.doi.org/10.12660/oit.v5n3.5776

Mat Som, A.P., Marzuki, A., Yousefi, M., \& AbuKhalifeh, A.N. (2012). Factors Influencing Visitors' Revisit Behavioral Intentions: A Case Study of Sabah, Malaysia. International Journal of Marketing Studies, 4(4). http://dx.doi.org/10.5539/ijms.v4n4p39

Mlozi, S., \& Pesämaa, O. (2013). Adventure tourist destination choice in Tanzania. Current Issues in Tourism, 16(1), 63-95. https://doi.org/10.1080/13683500.2011.647807

Oliver, R.L. (1993). Cognitive, Affective, and Attribute Bases of the Satisfaction Response. Journal of Consumer Research, 20(3), 418-430. https://doi.org/10.1086/209358

Orth, U., Stöckl, A., Veale, R., Brouard, J., Cavicchi, A., Faraoni, M., Larreina, M., Lecat, B., Olsen, J., Rodriguez-Santos, Santini, C., Wilson, D. (2012). Using attribution theory to explain tourists' attachments to place-based brands. Journal of Business Research, 65(9), 1321-1327. https://doi.org/10.1016/j.jbusres.2011.10.027

Ouyang, Z., Gursoy, D., \& Sharma, B. (2017). Role of trust, emotions and event attachment on residents' attitudes toward tourism. Tourism Management, 63, 426-438. https://doi.org/10.1016/j.tourman.2017.06.026

Pestana, M.H., Parreira, A., \& Moutinho, L. (2020). Motivations, emotions, and satisfaction: The keys to a tourism destination choice. Journal of Destination Marketing \& Management, 16 (100332), 1-9. https://doi.org/10.1016/j.jdmm.2018.12.006

Piscitelli, A. (2007). Exotismo e autenticidade: relatos de viajantes à procura de sexo [Exoticism and authenticity: reports of travelers looking for sex]. Cadernos Pagu, (19), 195-231 (in portuguese). http://dx.doi.org/10.1590/S0104-83332002000200009

Plunkett, D., \& Brooks, T.J. (2018). Examining the relationship between satisfaction, intentions, and post-trip communication behaviour of active event sport tourists. Journal of Sport and Tourism, 22(4), 303-313. https://doi.org/10.1080/14775085.2018.1532806

Prayag, G., \& Ryan, C. (2012). Antecedents of tourists' loyalty to mauritius: The role and influence of destination image, place attachment, personal involvement, and satisfaction. Journal of Travel Research, 51(3), 342-356. https://doi.org/10.1177/0047287511410321

Rajesh, R. (2013). Impact of Tourist Perceptions, Destination Image and Tourist Satisfaction on Destination Loyalty: A Conceptual Model. PASOS Revista de Turismo y Patrimonio Cultural, 11(3), 67-78.

Ram, Y., Björk, P., \& Weidenfeld, A. (2016). Authenticity and place attachment of major visitor attractions. Tourism Management, 52, 110122. https://doi.org/10.1016/j.tourman.2015.06.010

Scannell, L., \& Gifford, R. (2010). Defining place attachment: A tripartite organizing framework. Journal of Environmental Psychology, 30(1), 1-10. https://doi.org/10.1016/j.jenvp.2009.09.006

Seetanah, B., Teeroovengadum, V., \& Nunkoo, R. (2020). Destination satisfaction and revisit intention of tourists: does the quality of airport services matter? Journal of Hospitality \& Tourism Research, 44(1), 134-148. https://doi.org/10.1177/1096348018798446

Songshan, S.H., Cathy, H.C., \& Hsu (2009). Effects of Travel Motivation, Past Experience, Perceived Constraint, and Attitude on Revisit Intention. Journal of Travel Research, 48(1), 29-44. https://doi.org/10.1177/0047287508328793

Su, L.J., Hsu, M.K., \& Marshall, K.P. (2014). Understanding the Relationship of Service Fairness, Emotions, Trust, and Tourist Behavioral Intentions at a City Destination in China. Journal of Travel and Tourism Marketing, 31(8), 1018-1038. https://doi.org/10.1080/10548408.2014.892466

Sukiman, M.F., Omar, S.I., Muhibudin, M., Yussof, I., \& Mohamed, B. (2013). Tourist Satisfaction as the Key to Destination Survival in Pahang. Procedia - Social and Behavioral Sciences, 91, 78-87. https://doi.org/10.1016/j.sbspro.2013.08.404

Teixeira, S.J., \& Ferreira, J.J.M. (2019). Entrepreneurial artisan products as regional tourism competitiveness. International Journal of Entrepreneurial Behaviour and Research, 25(4), 652-673. https://doi.org/10.1108/IJEBR-01-2018-0023

Tlili, H.T., \& Amara, D. (2016). Towards Emotional Experience and Place Attachment as Tourist Satisfaction Attributes. Journal of Business \& Economic Policy, 3(3), 108-119.

Truong, T.L.H., Lenglet, F., \& Mothe, C. (2018). Destination distinctiveness: Concept, measurement, and impact on tourist satisfaction. Journal of Destination Marketing and Management, 8(January 2018), 214-231. https://doi.org/10.1016/j.jdmm.2017.04.004.

Wang, S., \& Chen, J.S. (2015). The influence of place identity on perceived tourism impacts. Annals of Tourism Research, 52, 16-28. https://doi.org/10.1016/j.annals.2015.02.016

Xu, X., Liu, W., \& Gursoy, D. (2019). The impacts of service failure and recovery efforts on airline customers' emotions and satisfaction. Journal of Travel Research, 58(6), 1034-1051. https://doi.org/10.1177/0047287518789285

Yang, J., Gu, Y., \& Cen, J. (2011). Festival tourists' emotion, perceived value, and ,behavioral intentions: A test of the moderating effect of festivalscape. Journal of Convention and Event Tourism, 12(1), 25-44. https://doi.org/10.1080/15470148.2010.551292

Yuksel, A., Yuksel, F., \& Bilim, Y. (2010). Destination attachment: Effects on customer satisfaction and cognitive, affective and conative loyalty. Tourism Management, 31(2), 274-284. https://doi.org/10.1016/j.tourman.2009.03.007

Yuksel, A., Yuksel, F., \& Bilim, Y. (2010). Destination attachment: Effects on customer satisfaction and cognitive, affective and conative loyalty. Tourism Management, 31(2), 274-284. https://doi.org/10.1016/j.tourman.2009.03.007

Zenker, S., Braun, E., \& Petersen, S. (2017). Branding the destination versus the place: The effects of brand complexity and identification for residents and visitors. Tourism Management, 58, 15-27. https://doi.org/10.1016/j.tourman.2016.10.008

*** Instituto Nacional de Estatística [National Institute of Statistics] (2018). Resultados definitivos Província de Luanda [Definitive results of Luanda Province] (in portuguese). http://censo.ine.gov.ao/xportal/xmain?xpid=censo2014\&xpgid=relatorios-censo2014\&actualmenu $=8377701 \&$ fbclid=IwAR3 NsZFMn448xHNoC2SKL8N6k5NyxjED9f--Ykv3NfBX3AdKJmc8o-v-Ve8

*** Ministério da Hotelaria e Turismo [Ministry of Hospitality and Tourism] (2018), Anuário estatístico do Turismo [Statistical Yearbook of Tourism], Luanda, Angola. 